\title{
Revisiting the Motivations behind Remittance Behavior: Evidence of Debt-Financed Migration from Afghanistan
}

\author{
Craig Loschmann and Melissa Siegel ${ }^{\dagger}$ \\ Maastricht Graduate School of Governance | UNU-MERIT \\ Working Version: August 12, 2013 \\ [Please do not cite without permission]
}

\begin{abstract}
In an insecure environment like Afghanistan, many families consider establishing household members at different geographic locations as a way to hedge against risks to a sustainable livelihood. In this study we examine whether such a location-based household strategy rests on remittances as an alternative source of income, exploiting the way in which migration is financed as a discriminating factor. Ultimately, our results show remittance transfers are in fact lower for debt-financed migrants, and the influence of certain individual and household characteristics of interest are in line with what we would expect if altruism is the dominating motivation. In light of this finding, we conclude that the sending of a household member abroad as a risk-coping strategy may be less about having an alternative source of income and more about having an alternative location to escape to if the security situation happens to take a turn for the worse.
\end{abstract}

Keywords: migration, remittance behavior, debt, risk, Afghanistan

JEL classification: F22, F24, O15

\footnotetext{
${ }^{\dagger}$ UNU-MERIT | Maastricht Graduate School of Governance, Keizer Karelplein 19, 6211 TC Maastricht, the Netherlands. Corresponding author: c.loschmann@maastrichtuniversity.nl
} 


\section{Introduction}

Within the overall discussion concerning migration and development, the issue of remittances is of great interest for both academics and policymakers alike. Cross-border transfers to lowincome countries of origin have shown resilient growth in the face of the recent economic downturn $^{1}$, providing further proof of its significance for many households throughout the developing world. Still, any potential positive impact on household welfare is not automatic and likely very much related to what motivates money to be sent in the first place. A migrant remitting under the pretense of paying for a family member's education for example has different implications than if it were for building a house in preparation for an eventual return. It is with this in mind that a plethora of empirical analysis has been carried out over the years looking to identify the determinants of remittance behavior. While these studies' findings have helped advance our understanding of the issue, there still remains a great deal of ambiguity when it comes to less scrutinized forms of migration flows from environments characterized by systematic insecurity.

In this study we investigate the motivations behind remittance behavior of Afghan migrants, utilizing the way in which migration is financed as a discriminating factor. In line with the theoretical underpinnings of the new economics of labor migration where migration is understood as a household strategy, we look at whether the costs of migration are covered by taking on a loan and the influence this has on the remittance behavior of the migrant once abroad. In this way, we are able to infer whether remittances are the product of debt-financed migration in light of an implicit contractual agreement between migrant and household of origin suggesting an explicit household risk-coping strategy. To the best of our knowledge, such an indicator used to distinguish remittance motivations has been employed only in a few other cases (Brown, 1997; Gubert, 2002), and never in a (post-) conflict environment similar to that of Afghanistan.

Exploring the underlying determinants of remittances is well-understood to be highly sensitive to the local contextual environment, with the Afghan setting being unique for a number of reasons.

\footnotetext{
${ }^{1}$ See the "Migration and Development Brief 20" published April 19, 2013 by the World Bank's Migration and Remittances Unit, Development Prospects Group.
} 
Most salient is the fact that Afghanistan ranks near the bottom of the list in terms of overall human development. ${ }^{2}$ The most recent National Risk and Vulnerability Assessment for Afghanistan (NRVA) published in 2009 estimated some 9 million people, or 36 percent of the population, living in absolute poverty without the ability to meet his or her basic needs. Clearly this abject impoverishment is closely related to conflict which has plagued the country for over three decades. As a result, large portions of the population at one time or another were left no choice but to take refuge outside the country, predominately in neighboring Iran and Pakistan. While the fall of the Taliban in 2001 resulted in massive return, the uncertainty of underdevelopment and insecurity persists leaving many to consider their alternatives if the situation takes a turn for the worse once more. It should come as no surprise then that many families make the decision to have one or more household members at different geographic locations as a way to hedge against a possible negative shock to their livelihood. Whether such a location-based household strategy however rests on remittance transfers as an alternative source of income or is simply a way to have a place to flee towards if the security situation becomes untenable remains uncertain.

The remainder of the analysis is structured as follows. We first review the relevant theoretical and empirical literature regarding the motivations to remit, followed by a presentation of our dataset and the descriptive depiction it reveals. We then go on to explain the empirical strategy employed before turning to the results. Finally, we conclude with a brief summary of our findings.

\section{Existing Literature}

Prior to any discussion concerning the motivations to remit, it is helpful to first briefly reflect on the determinants of migration given it is a prerequisite to remittances being sent. Traditionally migration theory originates from neo-classical economic thought focusing exclusively on the earnings gap between two locations. From this perspective, an individual moves to a destination if it maximizes expected utility based on a simple cost-benefit calculation (Harris and Todaro, 1970). Therefore the decision to migrate depends predominately on certain individual

\footnotetext{
${ }^{2}$ UNDP's Human Development Index taking into consideration indicators of Health, Education and Income ranks Afghanistan 175 out of 187 countries with comparable data in 2012.
} 
characteristics determining where s/he will be most productive and earn the highest income including age, experience, education, skills and the like (Massey et al., 1993).

Looking beyond merely the individual however, the new economics of labor migration hypothesizes that the decision to migrate is not taken by just the potential migrant but within a larger social context typically incorporating the household or greater family. Migration therefore is driven by a collective effort to not merely maximize income, but also minimize risks to income generation (Stark and Bloom, 1985; Taylor and Dyer, 2009). As such, migration is viewed as a means by which the household is able to increase capital assets, diversify sources of income and provide income insurance. Naturally then remittances enter the picture as one such channel through which the migrant is able to contribute to household well-being.

Stemming from the general premise of the new economics of labor migration, the contemporary debate around the determinants of remittances began in earnest with the seminal paper by Lucas and Stark (1985), "Motivations to Remit: Evidence from Botswana". Here the authors go beyond the previously unqualified presumption that migrants send money merely because they care for those left behind, and provide a systematic theory of remittance behavior determined by one of three possibilities: "pure altruism", "pure self-interest" or "tempered altruism/enlightened selfinterest". It is from this framework that the majority of contemporary empirical work on the subject builds.

Under the first motivation, "pure altruism", migrants are understood to derive utility from their family's well-being. As such, remittance behavior ${ }^{3}$ is expected to be increasing with migrant income $^{4}$ and decreasing with household income net of remittances, both of which are commonly found throughout the empirical literature (Hagen-Zanker and Siegel, 2007). Beyond the influence of migrant and household income however which alone fail to exclusively identify altruism in comparison to others explanations, a common approach is to model the influence of

\footnotetext{
${ }^{3}$ Remittance behavior here is used to indicate both the propensity to remit as well as the amount remitted. While some authors argue that both decisions may be made separately with possible different variables determining each, we follow Amuedo-Dorante and Pozo (2006, p. 240) who contend, "it is difficult to conceive of factors that affect the decision to remit money home, but do not influence the amount remitted by the immigrant".

${ }^{4}$ Because of data limitations, migrant income is commonly proxied by other migrant characteristics which are likely to influence the migrant's income function including age, gender, level of education, time abroad, etc.
} 
other relevant factors including the presence of more than one migrant from the same household, household size and duration of time abroad. Regarding the former, Agarwal and Howoritz (2002) compare single migrant to multiple migrant households in Guyana, under the hypothesis that if altruism is the main driver of remittance behavior than it should be decreasing in the presence of other migrants given responsibility to care for those back home is spread evenly among all family members abroad. Ultimately their finding of a statistically significant and negative relation between multiple migrant households and remittance behavior provides support for such a notion, and has been corroborated elsewhere (Naufal, 2008). As for household size, remittance behavior motivated by altruism is expected to be increasing with the greater number of family members there are to care for, and has been found in number of cases (Agarwal and Howoritz, 2002; Gubert, 2002; Osili, 2007). For the duration of time abroad, the "remittance decay" hypothesis expects remittance behavior under altruism to be decreasing over time due to an assumed weakening of social ties between migrant and household. Despite being found in certain cases (Holst and Schrooten, 2006; Vargas-Silva, 2006), remittance behavior is also commonly seen to follow an inverted U-curve in that it initially is increasing as migrants become more established at destination and thus have greater capacity to earn and send, and only later declines as social contact wanes (Carling, 2008).

Under various forms of "pure self-interest", migrants are understood to send money without the well-being of the family explicitly in mind but rather as the name indicates considering only their own personal benefit. A migrant with aspirations to inherit may be one such case implying the opposite of the altruism hypothesis in that remittance behavior should be increasing with household wealth, something Lucas and Stark (1985) themselves found evidence of in the case of Botswana. Alternatively, remittance behavior driven by self-interest may be witnessed when money is sent in order to acquire physical assets like land, housing, livestock and the like in preparation for an ensuing return. Thus when possible its convenient to include whether the migrant intends to return and the effect this has on remittance behavior, as shown in certain cases which provide evidence of the self-interest explanation (Brown, 1997; de la Briere, 1997).

Lastly under "tempered altruism/enlightened self-interest", remittances are seen as "part of an intertemporal, mutually beneficial contractual arrangement between migrant and home" (Lucas 
and Stark, 1985, p. 904). This would be the case for instance if remittances were driven by a desire to repay the family for an initial investment in education or costs associated with migration. Remittance behavior therefore would be expected to be increasing in light of such formal or informal past economic exchanges including a loan to migrate, a finding which has been found in certain contexts (Brown, 1997; Gubert, 2002). Alternatively, if migration of a family member is a strategy to diversify sources of income and thus reduce risk, then money sent home can be understood as a form of co-insurance for both migrant and household. The common approach to measure co-insurance includes focusing on the influence of the migrant's risk level or a fluctuation, or shock, to household income. For the former, Amuedo-Dorantes and Pozo (2006) use an indirect measure of migrant income risk and find robust evidence that remittance behavior is increasing with uncertainty in the host country pointing to both family and selfinsurance. Batistas and Umblijs (2012) use a more direct measure of migrant income risk and similarly find remittance behavior is increasing with migrant risk aversion which again points to self-insurance. For the latter, Lucas and Stark (1985) themselves find evidence of remittance behavior increasing with a drought in the case of Botswana, while Pleitez-Chavez (2004) supports such a finding when exploiting data on negative household income shocks in El Salvador.

Table 1 sums ups the predicted relationship of remittance behavior with certain key characteristics of both the migrant and household at origin under all three motivation scenarios. While not exhaustive, each characteristic is commonly incorporated into the dozens of empirical analyses developed since Lucas and Stark (1985). The underlying objective has been to use these in order to differentiate one dominant motive from the others. Still, in reality it is very likely that a mixture of motives at varying degrees exist within the same individual, not to mention heterogeneous individuals within a local context (Rapaport and Docquier, 2006). Lucas and Stark in fact highlight the combination of altruistic and self-interested factors which allow for any arrangement between migrant and household as characterized by "tempered altruism/enlightened self-interest" to be self-reinforcing. Therefore even though a single explanatory determinant is sought out, it is important to keep in mind the inherent interdependencies between motives when developing an appropriate empirical identification strategy. 
Table 1: Theoretical Relationships

\begin{tabular}{|c|c|c|c|c|}
\hline Motivation & $\begin{array}{c}\text { Pure } \\
\text { Altruism }\end{array}$ & $\begin{array}{c}\text { Pure } \\
\text { Self-Interest }\end{array}$ & $\begin{array}{r}\text { Tem } \\
\text { Enlight }\end{array}$ & $\begin{array}{l}\text { ruism/ } \\
\text {-Interest }\end{array}$ \\
\hline Description & $\begin{array}{c}\text { Utility derived from } \\
\text { household well- } \\
\text { being }\end{array}$ & $\begin{array}{c}\text { Aspirations to } \\
\text { inherit or investment } \\
\text { in assets }\end{array}$ & Repayment & Co-insurance \\
\hline Migrant Income & + & + & + & - \\
\hline Household Income & - & + & $+/-$ & - \\
\hline Household Size & + & & & \\
\hline $\begin{array}{l}\text { Negative Shock to } \\
\text { Household Income }\end{array}$ & + & & & + \\
\hline $\begin{array}{l}\text { Migrant Intent } \\
\text { to Return }\end{array}$ & & + & & \\
\hline Migrant Risk Level & & & & + \\
\hline $\begin{array}{l}\text { Multiple Migrants } \\
\text { from Household }\end{array}$ & - & & & \\
\hline Time Abroad & + then - & & - & \\
\hline
\end{tabular}

In regards to context, even though the environments of the above studies vary migration in each is noticeably characterized by labor flows towards either the US or Western Europe with little consideration given to other forms of migration from (post-) conflict settings. Certain studies however do provide insight into the remittance behavior of refugees which allow for a better understanding of migrant to household transfers when situated within a paradigm of insecurity. Al-Ali et al. (2001) for instance analyze the transnational behavior of both Bosnian and Eritrean refugees in Western Europe and notice that while many do send money home, most appear to do so because of social pressure either by their own households or by the community at large. Lindley (2009) looks at Somali refugees in London, finding similar evidence that while many do remit, it seems less because of a pre-migration strategy to diversify income and more because of post-hoc considerations for those left behind and what Riak Akuei (2005) calls "unforeseen burdens". 
Overall, it is clear in reviewing the literature that no generalized empirical finding emerges given the considerable differences in analytical approach and migration context under study. And while it appears official refugees are less inclined to send remittances as part of an explicit household strategy, this may not be the case for all migrants who may not be officially considered refugees but are still in essence compelled to leave their place of origin due to widespread uncertainty. In this regard it's important to consider the fine line between voluntary and involuntary movement, which is finer still in a (post-) conflict setting like that of Afghanistan.

\section{Data and Descriptive Statistics}

The data used in this analysis originates from an Afghanistan household survey collected for the IS Academy "Migration \& Development: A World in Motion" project. ${ }^{5}$ Even though a purely random sample throughout the country was not possible due to the limitations of conducting fieldwork in certain high-risk areas, particular attention was paid to capturing the diversity of the population in order to increase the representativeness of the sample. In this regard five provinces: Kabul, Herat, Balkh, Nangarhar and Kandahar were chosen because of their highly populated urban centers, geographical dispersion and varied profiles of migration. Within each province urban, semi-rural and rural communities were stratified as a way to capture different socioeconomic groups ${ }^{6}$, and these communities were then identified to be eligible for enumeration at random. Ultimately, the survey captures information regarding migration, remittances and more for a total of 2,005 households over 100 communities.

Table 2 provides a breakdown of the descriptive statistics for our sample. The final dataset used incorporates 210 migrants aged 15 and older who were identified as living abroad for at least 2 months at time of survey. Of that total 136 have remitted within 12 months of the survey taking place, sending an average total amount of US\$1,242. For our purposes, just over half of all migrants, 53 percent, financed their journey through either formal or informal loans from family or friends, similar to the 52 percent when looking at remitting migrants only.

\footnotetext{
${ }^{5}$ Funding for the project was provided by the Dutch Ministry of Foreign Affairs and the International Organization for Migration. For more information, see the project homepage: http://mgsog.merit.unu.edu/ISacademie/index.php.

${ }^{6}$ Urban refers to those communities which are the district capital; Semi-Rural refers to those communities which share a common border with the district capital; and Rural refers to those communities with no common border with the district capital.
} 
Table 2: Descriptive Statistics (sample means and standard deviations)

\begin{tabular}{|c|c|c|c|}
\hline Variable & Description & $\begin{array}{c}\text { All } \\
\text { Migrants } \\
(\mathrm{n}=210)\end{array}$ & $\begin{array}{c}\text { Remitting } \\
\text { Migrants } \\
(\mathrm{n}=136)\end{array}$ \\
\hline \multicolumn{4}{|l|}{ Independent Variables } \\
\hline Remit & Dummy indicating migrant remitted in the past 12 months & $\begin{array}{c}0.6476 \\
(0.4789)\end{array}$ & $\begin{array}{c}1 \\
(-)\end{array}$ \\
\hline Remit Total & Log of the total amount sent (in USD) & $\begin{array}{l}4.0056 \\
(3.2122)\end{array}$ & $\begin{array}{c}6.1851 \\
(1.5471)\end{array}$ \\
\hline \multicolumn{4}{|l|}{ Dependent Variables } \\
\hline \multicolumn{4}{|l|}{ Migrant Characteristics } \\
\hline Debt-Financed Migration & Dummy indicating migration was financed through a loan & $\begin{array}{c}0.5333 \\
(0.5001)\end{array}$ & $\begin{array}{c}0.5221 \\
(0.5014)\end{array}$ \\
\hline HH Head & Dummy indicating migrant is the household head & $\begin{array}{c}0.0524 \\
(0.2233)\end{array}$ & $\begin{array}{c}0.0441 \\
(0.2061)\end{array}$ \\
\hline Son of HH Head & Dummy indicating migrant is the son of household head & $\begin{array}{c}0.6810 \\
(0.4672)\end{array}$ & $\begin{array}{c}0.7426 \\
(0.4388)\end{array}$ \\
\hline Brother of HH Head & Dummy indicating migrant is the brother of household head & $\begin{array}{c}0.1952 \\
(0.3973)\end{array}$ & $\begin{array}{c}0.1838 \\
(0.3888)\end{array}$ \\
\hline Married & Dummy indicating migrant is married & $\begin{array}{c}0.3238 \\
(0.4690)\end{array}$ & $\begin{array}{c}0.3015 \\
(0.4606)\end{array}$ \\
\hline Age & Age of migrant & $\begin{array}{l}25.4667 \\
(8.7731)\end{array}$ & $\begin{array}{l}25.2206 \\
(7.9932)\end{array}$ \\
\hline Secondary Education & Dummy indicating migrant has at least secondary attainment & $\begin{array}{c}0.1143 \\
(0.3189)\end{array}$ & $\begin{array}{c}0.1250 \\
(0.3319)\end{array}$ \\
\hline Employed & Dummy indicating migrant is employed at destination & $\begin{array}{c}0.4952 \\
(0.5012)\end{array}$ & $\begin{array}{c}0.5809 \\
(0.4952)\end{array}$ \\
\hline Time Abroad & Number of years at destination & $\begin{array}{c}2.2020 \\
(1.7377)\end{array}$ & $\begin{array}{c}2.4632 \\
(1.6814)\end{array}$ \\
\hline \multicolumn{4}{|l|}{ Household Characteristics } \\
\hline HH Income & $\begin{array}{l}\text { Log of average monthly household income per capita } \\
\text { excluding remittances (in USD) }\end{array}$ & $\begin{array}{c}2.7784 \\
(1.1686)\end{array}$ & $\begin{array}{c}2.6576 \\
(1.15136)\end{array}$ \\
\hline HH Size & Number of household members & $\begin{array}{c}8.8000 \\
(2.4137)\end{array}$ & $\begin{array}{c}8.9632 \\
(2.2324)\end{array}$ \\
\hline Other Migrants & Number of other migrants from the same household & $\begin{array}{c}0.6286 \\
(1.2699)\end{array}$ & $\begin{array}{c}0.4338 \\
(0.9002)\end{array}$ \\
\hline
\end{tabular}

Beyond the factors to be used in our empirical model, we also have basic information regarding the purpose and regularity of remittances being sent which helps to provide context. Of those 
migrants that transferred money home, 56 percent did so without any particular reason in mind while another 25 percent did so to be spent on daily needs, 9 percent on ceremonies like wedding or funerals, 7 percent on debt payments and 2 percent for healthcare or education. As for regularity, 10 percent of migrants sent money every month while another 38 percent every 6 months, 28 percent every year and 25 percent irregularly.

Lastly, it is important to highlight that only 13 percent of our sample indicate their decision to migrate was due at least in part to security or political reasons. The large majority, 74 percent, decided to move in search of employment opportunities, while another 10 percent left because of family reunification or formation. As such, we are unable to make a blank statement regarding the involuntary nature of migration for the context in question. Nevertheless as was stressed prior, it is our contention that taking into consideration the lack of livelihood opportunities and systematic insecurity throughout Afghanistan, it is not presumptuous to assume many of the migrants in our sample were pressured to move either directly or indirectly out of sheer desperation, which must be at the very least kept in mind when considering remittance behavior once abroad.

\section{Methodology}

As stated, our main objective is to highlight the relationship between an implicit risk-coping household arrangement, indicated by debt-financed migration, and remittance behavior. The empirical strategy incorporates identification at both the extensive and intensive margin, and includes a range of individual and household characteristics that have been recognized in the literature to likely influence remittance behavior. The basic reduced form equation of interest expressing remittance behavior is:

$$
\text { Remit }_{i}=\mathrm{f}\left(\text { Debt_Mig }_{i}, X_{i}, Z_{i}\right)
$$

where Debt_Migi indicates whether migration was financed by taking on a formal or informal loan from family and friends; $X_{i}$ indicates characteristics of the individual migrant; and $Z_{i}$ indicates characteristics of the receiving household at origin linked to that migrant. 
In estimating this equation however, it is necessary to take into account that a substantial portion of our sample, 35\%, do not remit. Therefore because the distribution of our dependent variable, remittance behavior, is both of a discrete and continuous nature an OLS estimation would lead to biased and inconsistent results. In order to deal with this censored dependent variable we employ a zero-censored tobit model expressed by the following equation:

$$
\text { Remit }_{i}=\alpha_{0}+\beta_{1} \text { Debt_Migi }_{-}+\beta_{2} X_{i}+\beta_{3} Z_{i}+u_{i}
$$

where:

$$
\begin{aligned}
\text { Remit }_{i} & =\max \left(0, \text { Remit }_{i}\right) \\
u_{i} & \sim N\left(0, \sigma^{2}\right) .
\end{aligned}
$$

As indicated, the standard tobit model assumes linearity of the latent variable and censors the amount remitted to equal 0 if the migrant does not remit. While another option is to use a twostep Heckman selection model, there is little theoretical or empirical evidence to assume different factors influence the propensity to remit and the amount remitted, making this type of specification highly sensitive to identification exclusion (Gubert, 2002; Amuedo-Dorantes and Pozo, 2006). The zero-censored tobit model on the other hand allows the same covariates to influence both functions while assuming normality and homoscedasticity of the residuals.

\section{Results}

Table 3 provides the estimates of the tobit model for the total amount remitted over the past year. Apart from the coefficients along with robust standard errors, the marginal effects for the probability of remitting and the amount remitted if remitting are also presented.

Looking first at our principle variable of interest, we notice remittance behavior is decreasing with debt-financed migration and the result is statistically significant at the 10 percent level. Indeed, those migrants who took on a formal or informal loan to help pay for their trip are on the margin 7 percentage points less likely to send remittances in the first place. And when they do send, the level of remittances is 0.56 less of the log total amount. This finding runs directly counter to the hypothesis that remittances may be part of a risk-coping strategy which involves debt-financed migration. While this may indicate debt-financed migrants are simply less capable 
of sending remittances because they originate from poorer households in the first place, a simple mean difference test of household income between the groups shows no significant difference ruling out such a notion.

Table 3: Tobit Estimates for the Total Amount Remitted

\begin{tabular}{|c|c|c|c|c|}
\hline & Coefficient & Robust SE & $\begin{array}{c}\text { Marginal Effect: } \\
\text { Probability of } \\
\text { Remitting } \\
\end{array}$ & $\begin{array}{c}\text { Marginal Effect: } \\
\text { Amount Remitted } \\
\text { if Remitting }\end{array}$ \\
\hline constant & $-9.7994 * *$ & $(3.9132)$ & & \\
\hline Debt-Financed Migration & $-0.9341 *$ & $(0.5583)$ & $-0.0731 *$ & $-0.5623 *$ \\
\hline HH Head & 2.0071 & $(2.2068)$ & 0.1212 & 1.3588 \\
\hline Son of HH Head & $4.0752 * *$ & $(1.8257)$ & $0.3700 * *$ & $2.1980 * *$ \\
\hline Brother of $\mathrm{HH}$ Head & 2.8767 & $(1.8938)$ & $0.1757 * *$ & 1.9404 \\
\hline Married & -0.1910 & $(0.8351)$ & -0.0152 & -0.1139 \\
\hline Age & 0.0290 & $(0.1907)$ & 0.0023 & 0.0174 \\
\hline Age_squared & 0.0005 & $(0.0028)$ & 0.0000 & 0.0003 \\
\hline Secondary Education & 0.0713 & $(0.8901)$ & 0.0056 & 0.0429 \\
\hline Employed & $2.6682 * * *$ & $(0.8539)$ & $0.2090 * * *$ & $1.6030 * * *$ \\
\hline Time Abroad & $3.1172 * * *$ & $(0.5394)$ & $0.2462 * * *$ & $1.8676^{* * *}$ \\
\hline Time Abroad_squared & $-0.3502 * * *$ & $(0.0791)$ & $-0.0277 * * *$ & $-0.2098 * * *$ \\
\hline HH Income & $-0.9861 * * *$ & $(0.2506)$ & $-0.0779 * * *$ & $-0.5908 * * *$ \\
\hline HH Size & $0.2927 * *$ & $(0.1333)$ & $0.0231 * *$ & $0.1754 * *$ \\
\hline Other Migrants & $-1.0507 * * *$ & $(0.3909)$ & $-0.0830 * *$ & $-0.6295 * * *$ \\
\hline \multicolumn{5}{|l|}{ Controls } \\
\hline Migrant Destination & $\mathrm{Y}$ & & & \\
\hline HH Ethnicity & $\mathrm{Y}$ & & & \\
\hline HH District Type & $\mathrm{Y}$ & & & \\
\hline HH Province & $\mathrm{Y}$ & & & \\
\hline Observations & 210 & & & \\
\hline Uncensored Observations & 136 & & & \\
\hline Adj. R-Squared & 0.1252 & & & \\
\hline
\end{tabular}

Note: $* \mathrm{p}<0.10, * * \mathrm{p}<0.05, * * * \mathrm{p}<0.01$ 
Regarding those characteristics of the migrant which are statistically significant, we observe sons of the household head are 37 percentage points more likely to send money home and send 2.20 more of the log total amount. Similarly, brothers of the household head have a higher propensity to remit, yet there is no statistical significance in terms of amount. Not surprisingly remittance behavior for those migrants who are employed abroad is likewise increasing, even though factors related to possible earnings potential including age and educational level are statistically insignificant. Lastly, the relationship with duration of time abroad appears to follow an inverted U-curve, with migrants early on showing an increasing propensity to remit at a higher level, before tapering off in the long run as indicated by the squared term.

Turning to household characteristics, we observe that a higher per-capita income is associated with a slightly lower propensity to remit by the migrant at a lower level, while in a similar vein larger households are more likely to receive remittances at a higher level. Additionally, remittance behavior is decreasing with the number of other migrants from the same household also abroad, as likelihood of sending remittances drops 8 percentage points for each additional migrant while absolute level declines 0.63 of the log total amount.

\section{Conclusion}

In this study, our goal has been to unpack the motivations behind remittance behavior of Afghan migrants by utilizing the way in which migration is financed as a discriminating factor. Our conjecture is that if remittances are sent as part of a household risk-coping strategy based on an implicit contractual agreement, then we should see a positive relationship between remittance behavior and whether the costs of migration are covered by taking on a loan. No such evidence however is found in the results of our empirical analysis. On the contrary, a debt-financed migrant is in fact less likely to send remittances and send less in absolute terms when remitting.

What's more, the effects of certain individual and household characteristics of interest are in line with what we would expect if altruism is the dominating explanation. Aside from the fact that remittance behavior is increasing with migrant employment and household size and decreasing with household income, relationships which by themselves fail to unambiguously explain 
remittances through altruism, the fact that remittance behavior is decreasing in the presence of more migrants from the same household indicates altruistic motivations. Furthermore, the inverted-U relationship regarding time abroad suggests remittance behavior increases in the early stages abroad as migrants adapt to their environment and increase their potential to earn, and only later declines as social contact with those at origin begins to fade.

Even though we do not find evidence that Afghan migrants in our sample send remittances as part of a household risk-coping arrangement, this is not to say that migration of a household member in and of itself is not part of any such strategy. Given the realities of the situation in Afghanistan, sending as household member abroad may be less about having an alternative source of income and more about having an alternative location to escape towards if the security situation takes a turn for the worse. Such a thought is particularly relevant in light of the upcoming withdrawal of international troops in 2014 and the understandable concern for a rise in insecurity which is widely believed to follow. 


\section{References}

Aga, G. A., Eigen-Zucchi, C., Plaza, S. and Silwal, A. R. (2013). "Migration and Development Brief 20". World Bank Migration and Remittances Unit, Development Prospects Group.

Agarwal, R. and Howoritz, A. W. (2002). "Are international remittances altruism or insurance? Evidence from Guyana using multiple-migrant households”. World Development, 30(11): 2033-2044.

Al-Ali, B., Black, R. and Koser, K. (2001). "The Limits to "Transnationalism": Bosnian and Eritrean Refugees in Europe as Emerging Transnational Communities". Ethnic and Racial Studies, 24 (4): 578-600.

Amuedo-Dorantes, C. and Pozo, S. (2006). "Remittances as insurance: evidence from Mexican immigrants". Journal of Population Economics, 19 (2): 227-254.

Batistas, C. and Umblijs, J. (2012). "Remittances and Individual Risk Preferences", mimeo, NORFACE Conference on "Migration: Global Development, New Frontiers".

Brown, R. P. C. (1997). "Estimating Remittance Functions for Pacific Island Migrants". World Development, 25 (4): 613-626.

Carling, J. (2008). "The determinants of migrant remittances", Oxford Review of Economic Policy, 24 (3): 582-599.

Central Statistics Organization, Islamic Republic of Afghanistan (2009). National Risk and Vulnerability Assessment 2007/8: A Profile of Afghanistan. Cologne: ICON-Institute GmbH \& Co KG Consulting Gruppe.

de la Briere, B., de Janvry, A., Lambert, S. and Sadoulet, E. (1997). "Why do Migrants Remit? An Analysis for the Dominican Sierra". Discussion Paper 37, Washington D.C., FCND.

Faini, R. (1994). "Workers remittances and the real exchange rate". Journal of Population Economics, 7 (2): 235-245.

Funkhouser, E. (1995). "Remittances from International Migration: A Comparison of El Salvador and Nicaragua". Review of Economics and Statistics, 23 (3): 219-234.

Gubert, F. (2002). "Do migrants insure those who stay behind? Evidence from the Kayes area (Western Mali)". Oxford Development Studies, 30 (3): 267-287.

Hagen-Zanker, J. and Siegel, M. (2007). "The Determinants of Remittances: A Review of the Literature". Working Paper 2007/03, Maastricht, Maastricht Graduate School of Governance. 
Harris, J. R. and Todaro, M. P. (1970). "Migration, unemployment, and development: twosector analysis". American Economic Review, 60: 126-142.

Holst, E. and Schrooten, M. (2006). "Migration and Money. What Determines Remittances? Evidence from Germany”. Discussion Paper 566, Berlin, German Institute for Economic Research.

Lindley, A. (2009). “The Early-Morning Phonecall: Remittances from a Refugee Diaspora Perspective". Journal of Ethnic and Migration Studies, 35 (8): 1315-1334.

Lucas, R. and Stark, O. (1985). "Motivations to Remit: Evidence from Botswana". Journal of Political Economy, 93 (5): 901-918.

Massey, D. S., Arango, J., Hugo, G., Kouaouci, A., Pelligrino, A. and Taylor, J.E. (1993).

"Theories of international migration: A review and appraisal". Population and Development Review, 19: 431-66.

Naufal, G. S. (2008). "Why Remit? The Case of Nicaragua". Discussion Paper No. 3276, Bonn, IZA.

Osili, U. O. (2007). "Remittances and Savings from International Migration: Theory and Evidence Using a Matched Sample”. Journal of Development Economics, 83 (2): 446465.

Pleitez-Chavez, R. A. (2004). Remittances as a Strategy to Cope with Systemic Risk: Panel Results from Rural Households in El Salvador. PhD thesis, the Ohio State University, Columbus, $\mathrm{OH}$.

Rapaport, H. and Docquier, F. (2006). “The Economics of Migrants Remittances”. In: S. Kolm and J. M. Ythier (eds.) Handbook of the Economics of Giving, Altruism and Reciprocity, Amsterdam: Elsevier/North-Holland.

Riak Akuei, S. (2005). "Remittances as Unforeseen Burdens: The Livelihoods and Social obligations of Sudanese Refugees”. Global Migration Perspective No. 18, University College of London, Global Commission on International Migration.

Stark, O. and Bloom, D. E. (1985). “The New Economics of Labor Migration”. American Economic Review, 75 (2): 173-178.

Taylor, J. E. and Dyer, G. A. (2009). "Migration and the Sending Economy: A Disaggregated Rural Economy-Wide Analysis”. Journal of Development Studies, 45 (6): 966-989. 
UNDP (2013) Human Development Report 2013. The Rise of the South: Human Progress in a Diverse World, New York: United Nations.

Vargas-Silva, C. (2006). "The Determinants of International Remittances: Evidence from the Legalized Population". Academy of Economics and Finance Papers and Proceedings, 30: 333-335. 